ISSN: 2085-0344 (Print)

ISSN: 2503-1864 (Online)

Journal homepage: www.ejournal.almaata.ac.id/literasi

Journal Email: literasi_stia@yahoo.com

\title{
Studi Komparasi Hasil Belajar Peserta Didik Melalui Model Pembelajaran Kontekstual dan Inovasi Guru di SDN 1 dan 3 Selang Kebumen
}

\author{
Siti Anisatun Nafi'ah, \\ Program Studi Pendidikan Guru Madrasah Ibtidaiyah \\ Sekolah Tinggi Agama Islam Nahdhatul Ulama Purworejo \\ Kledung, Banyuurip, Kliwonan, Kecamatan Purworejo, Kabupaten Purworejo, Jawa Tengah 54171 \\ email: anisnafiah14@gmail.com/monah09@yahoo.com

\section{Maemonah} \\ Fakultas Ilmu Tarbiyah dan Keguruan \\ Univeristas Islam Negeri Sunan Kalijaga \\ Jalan Laksda Adisucipto, Caturtunggal, Depok, Kabupaten Sleman, Daerah Istimewa Yogyakarta 55281
}

\begin{abstract}
This thesis aims to: (1) analyze the influence of contextual learning model on the learning outcomes of the third grade students of SDN 1 and 3 Selang, (2) analyze the influence of contextual learning model through teacher innovation on the learning outcomes of the third grade students of SDN 1 and 3 Selang (3) analyze the differences of contextual learning model and teacher innovation on the learning outcomes of the third grade students of SDN 1 and 3 Selang. This research was conducted in SDN 1 and 3 Selang using sequential explanatory research method. The first stage using qualitative method. Data collection techniques used were interviews, and observations. The second stage using quantitative. Data collection techniques used questionnaires, tests, observation sheets, performance tasks and projects. Data analysis techniques used were qualitative and quantitative. Based on the results, the learning outcomes of learners in the cognitive domain of contextual learning model don't give a significant influence compared to the contextual learning model through teacher innovation. The result of significance in the first is $0.302>0.05$, second is $0.244>0.05$, third is $0.081>0.05$, fourth is $0.923>0.05$, then Ho is accepted. The contextual learning model through teacher innovation gives a significant influence on the domain of attitude and psychomotor. The attitude is such as active, cooperative, and responsible. The psychomotor is such as observation, conclusion, money management, and saving skills.
\end{abstract}

Keywords: contextual learning model, teacher innovation, learning outcomes

\section{Abstrak}

Tesis ini bertujuan: (1) Menganalisis pengaruh model pembelajaran kontekstual terhadap hasil belajar peserta didik kelas III di SD N 1 dan 3 Selang. (2) Menganalisis pengaruh model pembelajaran kontekstual melalui inovasi guru terhadap hasil belajar peserta didik kelas III di SD N 1 dan 3 Selang. (3) Menganalisis perbedaan signifikansi hasil belajar peserta didik antara model pembelajaran kontekstual dan inovasi guru di SD N 1 dan 3 Selang. Penelitian ini menggunakan metode penelitian kombinasi jenis sequential explaratory. Pada tahap pertama menggunakan kualitatif. Pengumpulan data menggunakan wawancara, , observasi. Pengumpulan data kuantitatif yaitu angket, tes, lembar pengamatan, tugas unjuk kerja dan proyek. Teknik analisis data penulis melakukan analisis data kualitatif dan kuantitatif Hasil penelitian bahwa 
hasil belajar peserta didik pada ranah kognitif untuk model pembelajaran kontekstual tidak memberikan pengaruh yang signifikan dibandingkan model pembelajaran kontekstual melalui inovasi guru. Uji signifikansi dengan menggunakan uji mann whitney u. pertama 0,302 >0,05, kedua 0,244 >0,05, ketiga 0,081 >0,05 keempat 0,923 >0,05, dengan demikian Ho diterima. Model pembelajaran kontekstual dan inovasi guru memberikan pengaruh yang signifikan pada ranah sikap dan ketrampilan. Sikap seperti aktif, kerjasama, dan tanggungjawab, ketrampilan seperti pengamatan, kesimpulan, pengelolaaan uang, dan menabung.

\section{Kata Kunci: model pembelajaran kontekstual, inovasi guru, hasil belajar}

\section{PENDAHULUAN}

Model pembelajaran tidak dapat dipisahkan dalam dunia pendidikan terutama dalam proses pembelajaran. Model pembelajaran memiliki berbagai macam seperti kontekstual, direct instruction, dan kooperatif. Masing-masing model pembelajaran memiliki kelemahan dan kelebihan. Model pembelajaran yang digunakan oleh seorang guru di dalam kelas sangat menentukan hasil belajar peserta didik.

Jika seorang guru menggunakan model pembelajaran yang monoton berdampak pada hasil belajar peserta didik. Hasil belajar yang dimaksud oleh penulis seperti kognitif, sikap, dan ketrampilan peserta didik. Peserta didik kadang merasa jenuh ketika guru sedang mengajar di kelas. Jika seorang guru dapat menggunakan model pembelajaran yang tidak monoton seperti kontekstual maka peserta didik fun dalam belajar.

Menurut Wina Sanjaya "Contextual Teaching And Learning (CTL) adalah suatu strategi pembelajaran yang menekankan kepada proses keterlibatan siswa secara penuh untuk dapat menemukan materi yang dipelajari dan menghubungkannya dengan situasi kehidupan nyata sehingga mendorong siswa untuk dapat menerapkannya dalam kehidupan mereka. ${ }^{1}$ Menurut Elaine B Johnson CTL adalah sebuah sistem belajar yang didasarkan pada filosofi bahwa siswa mampu menyerap pelajaran apabila mereka menangkap makna dalam materi akademis yang mereka terima dan mereka

${ }^{1}$ Wina Sanjaya, Strategi Pembelajaran Berorientasi Standar Proses Pendidikan (Jakarta: Prenada Media, 2007), hlm. 255 menangkap makna dalam tugas-tugas sekolah jika mereka bisa mengaitkan informasi baru dengan pengetahuan dan pengalaman yang sudah meraka miliki sebelumnya. ${ }^{2}$

Menurut US Departmen of Educatio The National School-to Work Office Contextual teaching andlearning is a conception of teaching and learning thathelps teachers relate subject matter content to real world situations; and motivates students to make connections between knowledge and its applications to their lives asfamily members, citizens, and workers; and engage in the hard work that learning requires. ${ }^{3}$ (CTL merupakan suatu konsepsi yang membantu guru mengaitkan konten mata pelajaran dengan situasi dunia nyata dan memotivasi siswa membuat hubungan antara pengetahuan, dan penerapan dalam kehidupan mereka sebagai anggota keluarga, warga negara, dan tenaga kerja). ${ }^{4}$

Berdasarkan beberapa pendapat di atas dapat disimpulkan bahwa model pembelajaran kontekstual adalah model pembelajaran yang membantu seorang guru mengaitkan konten mata pelajaran dengan situasi dunia nyata,

${ }^{2}$ Elaine B. Johnson, Contextual Teaching And Learning: Menjadikan Kegiatan Belajar Mengajar Mengasyikan Dan Bermakna, Terj. Ibnu Setiawan (Bandung: Mizan Learning Centre, 2007), hlm. 14.

${ }^{3}$ Clemente Charles HUDSON dan Vesta R. WHISLER, "Contextual Teaching and Learning for Practitioners," Jurnal: Systemics, cybernetics and informatics volum 6, No 4, Tahun 2008. hlm. 54.

${ }^{4}$ Trianto, Mendesain Model Pembelajaran Inovatif, Progresif: Konsep, Landassan, dan Implementasinya pada Kurikulum Tingkat Satuan Pendidikan (Jakarta: Kencana Media Grup, 2012) hlm. 104. 
yang menekankan peserta didik untuk terlibat aktif dalam pembelajaran, sehingga peserta didik dapat termotivasi untuk memperoleh pengetahuan dan mendapatkan pengalaman. Konsep pembelajaran kontekstual tersebut memiliki tiga kata penting pertama, Guru harus kreatif dalam mengaitkan konten mata pelajaran dengan kehidupan sehari-hari peserta didik. Kedua, peserta didik harus aktif dalam pembelajaran kontekstual bukan pasif. Jika peserta didik aktif maka peserta didik dapat menemukan pengetahuan yang bermakna. Ketiga, peserta didik setelah memperoleh materi pembelajaran mampu mengaitkan dengan kehidupan sehari-hari.

Beberapa mata pelajaran di sekolah dasar (SD) seringkali mengaitkan kehidupan peserta didik baik dari sisi sosial, spiritual, atau sains. Guru dalam pembelajaran di kelas sering mengalami hambatan dalam proses pembelajaran untuk mengaitkan mata pelajaran dengan lingkungan peserta didik khususnya sosial atau ilmu pengetahuan sosial (IPS). Guru di SD $\mathrm{N} 1$ dan 3 Selang beranggapan bahwa IPS sangat sulit untuk dikonkritkan, karena sebagian besar materi merupakan materi yang abstrak, contoh jenis pekerjaan yang menghasilkan barang dan jasa, dokumen pribadi, dan keluarga. Peserta didik mengalami kesulitan untuk membedakan karena menurut guru materi tersebut terlalu tinggi bagi peserta didik. ${ }^{5}$ Dengan demikian model pembelajaran kontekstual relevan diterapkan di dalam pembelajaran karena model pembelajaran kontekstual mengarahkan peserta didik pada keadaan atau situasi yang nyata dengan tujuan untuk mengaitkan materi ke dalam kehidupan sehari-hari.

Menurut penulis dengan permasalahan di atas menunjukan bahwa materi IPS merupakan materi yang sulit bagi beberapa guru khususnya di SD N 1 dan 3 Selang. Materi IPS di SD tidak dapat dipisahkan dari kehidupan peserta didik. Berdasarkan fakta-fakta di sekolah bahwa guru dalam pembelajaran IPS lebih menekankan

${ }^{5}$ Olah data hasil wawancara dengan guru kelas II, III, IV dan VI di SD N 1 dan 3 Selang hafalan dan melupakan kehidupan nyata sehingga kurang bermakna bagi peserta didik. Maka dapat disimpulkan antara mata pelajaran, model pembelajaran, dan hasil belajar peserta didik harus berkesinambungan sehingga menghasilkan hasil belajar peserta didik yang maksimal.

Mata pelajaran IPS kelas rendah yaitu kelas 1, 2 dan 3 adalah mata pelajaran yang harus dipelajari oleh peserta didik. Peserta didik pada kelas rendah berkisar umur 6-9 tahun. Peserta didik pada umur tersebut berada pada tahap operasional konkret. Peserta didik pada tahap tersebut perlu belajar pada hal-hal yang konkret belum abstrak.

Mata pelajaran IPS untuk kelas 1 dan 2 hanya berada pada ruang lingkup yang sempit yaitu lingkungan keluarga dan tetangga rumah. Peserta didik pada kelas 3, materi mulai meluas yaitu mengenal lingkungan rumah, sekolah, jenis pekerjaan, dan uang. Peserta didik kelas 3 adalah masa peralihan menuju kelas tinggi. Maka peserta didik yang sedang mengalami masa peralihan dengan materi IPS yang mulai meluas, peserta didik dituntut memahami lingkungan sosial baik di sekolah ataupun rumah. Peserta didik terkadang akal dan pikiran mereka belum bisa memahami lingkungannya, sebagai contoh peserta didik belum mengenal orang-orang di lingkungan sekolah.

Guru di SD N 1 dan 3 Selang beranggapan bahwa mata pelajaran IPS kelas 3 terlalu tinggi untuk diajarkan ke mereka. Guru sering menemukan peserta didik sulit untuk memahami materi IPS. Cara guru memberikan materi IPS juga berbeda antara kelas tinggi dan rendah karena peserta didik pada kelas tinggi sudah mulai bisa berpikir secara abstrak. Penulis menemukan bahwa sebagian besar guru pada kelas tinggi terkendala pada media ketika mengajarkan mata pelajaran IPS. Hal ini berbeda pada kelas rendah penulis menemukan masalah yang lebih kompleks ketika guru mengajar IPS seperti materi, media, dan model pembelajaran. Oleh sebab itu guru penting untuk melakukan inovasi dalam pembelajaran. ${ }^{6}$

${ }^{6}$ Olah data Hasil Angket Tentang Pendapat Guru 
Menurut Santoso S Hamidjojo inovasi adalah " perubahan yang baru dan secara kualitatif berbeda dari hal (yang ada) sebelumnya dan sengaja diusahakan untuk meningkatkan kemampuan guna mencapai tujuan tertentu". ${ }^{7}$ Berbeda dengan Everret M Rogers mendefinisikan "invention as an idea, practice, or object that is perceived as new by an individual or another unit of adoption." 8 (Inovasi adalah suatu ide, praktik, atau objek yang disadari dan diterima sebagai suatu hal yang baru oleh seseorang atau kelompok untuk diadopsi.) pendapat Santoso S Hamidjojo dan Everret M Rogers diperjelas oleh pendapat Mattew B Miles yang menyatakan bahwa "inovasi adalah suatu perubahan yang sifatnya khusus, memiliki nuansa kebaruan dan disengaja melalui suatu program yang jelas dan direncanakan terlebih dahulu, serta dirancang untuk mencapai tujuan yang diharapkan dari suatu sistem." 9

Berdasarkan gagasan di atas dapat disimpulkan bahwa inovasi adalah suatu penemuan, ide, praktik yang dilakukan oleh seseorang atau kelompok secara sengaja untuk perubahan secara khusus yang berbeda dari sebelumnya sehingga tujuan dapat tercapai. Maka sesuatu disebut inovasi/pembaharuan kalau upaya yang baru itu terdapat tujuan yang dicapai walaupun masih sebagian saja. Inovasi yang paling penting dalam pendidikan adalah aspek proses pembelajaran karena akan memberikan efek pada hasil belajar peserta didik yang berbeda dari sebelumnya.

Inovasi yang dilakukan oleh seorang guru tentu terkait dengan pendidikan seperti model pembelajaran, media, dan materi. Inovasi pada model pembelajaran yang umumnya guru menggunakan model direct instruction. Guru

\footnotetext{
dalam Pembelajaran IPS di SD N 1 dan 3 Selang

${ }^{7}$ Din Wahyudin, dkk., Pengantar Pendidikan (Jakarta: Universitas Terbuka, 2010), hlm. 9.5 .

${ }^{8} \mathrm{Udin} \mathrm{S}$ Winataputra, dkk., Pembaharuan Pendidikan di SD (Jakarta: Universitas Terbuka, 2011), hlm. 1.3 hlm. 9.5

${ }^{9}$ Din Wahyudin, dkk., Pengantar Pendidikan ...,
}

mengubah dengan model pembelajaran seperti kontekstual.

Berdasarkan pemaparan di atas penulis ingin melakukan eksperimen. Eksperimen yang dilakukan oleh penulis adalah model pembelajaran kontekstual dan inovasi guru. Inovasi yang dilakukan oleh penulis dengan tiga cara yaitu model, media, dan materi.

Inovasi yang dimaksudkan dalam penelitian ini adalah dengan membuat variasi pada tahaptahap model pembelajaran kontektstual yang telah dibakukakan oleh Depdiknas. Inovasi pada model pembelajaran kontekstual yang dilakukan oleh penulis pada tahap inkuiri dan pemodelan. Inkuiri yang dilakukan oleh penulis dilakukan dengan dua cara yaitu dengan belajar secara teori dan aplikasi di dalam kehidupan seharihari. Pada tahap pemodelan penulis melakukan dengan dua cara yaitu pemodelan dari pesesrta didik dan pemodelan melalui gambar yag dapat ditiru oleh peserta didik. Inovasi pada media seperti guru sebelumnya jarang menggunakan media. Guru selanjutnya mengadakan media agar peserta didik lebih tertarik dalam belajar.

Inovasi pada materi misal peserta didik sulit memahami materi atau guru merasa kurang dengan materi maka guru menginovasikan materi sebagai wawasan bagi peserta didik. Tujuan dari inovasi sendiri bagi guru adalah untuk memaksimalkan tujuan yang hendak dicapai. Tujuan yang awalnya setiap materi hanya berada pada ranah kognitif saja kemudian berkembang menjadi sikap dan psikomotorik.

Eksperimen yang dilakukan oleh penulis dilakukan di dua sekolah yang berbeda. Alasan penulis melakukan komparasi di dua sekolah karena untuk mendapatkan data yang lebih valid. Jika penulis melakukan eksperimen dengan satu kelas dan satu sekolah data yang didapatkan tidak sesuai untuk dilakukan eksperimen, karena eksperimen harus memiliki kelas kontrol. Jika eksperimen tidak memiliki kelas kontrol maka banyak variabel yang tidak terkontrol. Maka penulis tertarik untuk melaksanakan eksperimen lebih lanjut dengan model pembelajaran kontekstual dan inovasi guru. 


\section{METODE PENELITIAN}

Metode penelitian yang digunakan dalam penelitian ini adalah kombinasi (mixed methods). . Menurut Creswell metode penelitian kombinasi adalah pendekatan penelitian yang mengombinasikan atau mengasosiasikan bentuk kualitatif dan bentuk kuantitatif. ${ }^{10}$ Pendapat Creswell diperjelas oleh Sugiyono yang berpendapat bahwa metode penelitian kombinasi adalah "suatu metode penelitian yang mengkombinasikan atau menggabungkan antara metode kuantitatif dan kualitatif yang digunakan secara bersama-sama dalam suatu kegiatan penelitian sehingga diperoleh data yang lebih komprehensif, valid, reliable dan obyektif." 11

Alasan penulis menggunakan penelitian kombinasi ingin memperoleh data dan informasi yang lengkap, valid, reliable dan obyektif. Peneliti juga ingin melakukan penelitian tindakan (action research), untuk menentukan tindakan yang teruji secara efektif. Pada tahap menemukan masalah atau hipotesis tindakan digunakan metode kualitatif. Pada saat melakukan pengujian digunakan metode kualitatif dan kuantitatif secara bersama-sama. Penulis memilih model kombinasi sequential explaratory design. Sequential explaratory design adalah metode yang pada tahap awal mengggunakan metode kualitatif dan pada tahap berikutnya menggunakan metode kuantitatif

Metode penelitian kualitatif digunakan untuk mendeskripsikan tentang pembelajaran IPS di SD N 1 dan 3 Selang. Teknik pengumpulan data yang digunakan dengan cara observasi, wawancara, dan dokumentasi. Observasi digunakan untuk mendapatkan data tentang pembelajaran di kelas. Wawancara untuk mendapatkan data awal tentang pembelajaran IPS di kelas. Dokumentasi untuk mendapatkan data tentang sumber belajar IPS dan hasil belajar peserta didik. Teknik analisis yang

${ }^{10}$ John W. Creswell, Research Design: Pendekatan Kualitatif, Kuantitatif, dan Mixed (Yogyakarta: Pustaka Pelajar, 2009), hlm. 5.

${ }^{11}$ Sugiyono, Metode Penelitian Kombinasi (Mixed Methods), (Bandung: Alfabeta, 2013), hlm. 404. digunakan adalah analisis miles and hubberman. Teknik analisis data meliputi beberapa tahapan pertama, pada tahap reduksi penulis melakukan wawancara dengan tujuan ingin mengetahui gambaran umum mengenai guru, dan peserta didik. Kedua, pada tahap penyajian data penulis mulai memfokuskan penelitian dengan cara hasil wawancara sebelumnya kemudian dilakukan observasi di dalam kelas untuk melihat gambaran lebih terperinci dan kevalidan data. Ketiga, pada tahap verivikasi penulis mulai menemukan kesimpulan awal hubungan antara variabel yaitu pengaruh model pembelajaran direct instruction terhadap hasil belajar peserta didik.

Penulis setelah selesai melakukan penelitian kualitatif selanjutnya penulis melakukan pengumpulan data dengan kuantitatif. Metode penelitian kuantitatif digunakan untuk menguji hipotesis. Metode penelitian kuantitatif pada penelitian ini adalah jenis penelitian komparasi. Penelitian komparasi diarahkan untuk mengetahui apakah antara dua atau lebih dari dua kelompok ada perbedaan dalam aspek atau variabel yang diteliti. Komparasi yang dilakukan dalam penelitian ini adalah dengan membandingkan model pembelajaran kontekstual dan model pembelajaran kontekstual melalui inovasi guru. Dengan demikian hipotesis yang diajukan oleh peneliti sebagai berikut

$\mathrm{Ho}_{1}$ : Tidak ada pengaruh signifikan hasil belajar peserta didik antara sebelum dan sesudah dilakukan pembelajaran dengan model pembelajaran kontekstual di SD N 1 dan 3 Selang Kebumen.

$\mathrm{Ha}_{1}$ : Ada pengaruh signifikan hasil belajar peserta didik antara sebelum dan sesudah dilakukan pembelajaran dengan model pembelajaran kontekstual di SD N 1 dan 3 Selang Kebumen.

$\mathrm{HO}_{2}$ : Tidak ada pengaruh signifikan hasil belajar peserta didik antara sebelum dan sesudah dilakukan pembelajaran dengan model pembelajaran kontekstual dan inovasi guru di SD N 1 dan 3 Selang Kebumen. 
$\mathrm{Ha}_{2}$ : Ada pengaruh signifikan hasil belajar peserta didik antara sebelum dan sesudah dilakukan pembelajaran dengan model pembelajaran kontekstual dan inovasi guru di SD N 1 dan 3 Selang Kebumen.

$\mathrm{HO}_{3}$ : Ada pengaruh signifikan hasil belajar peserta didik antara sebelum dan sesudah dilakukan pembelajaran dengan model pembelajaran kontekstual dan model pembelajaran kontekstual dan inovasi guru di SD N 1 dan 3 Selang Kebumen.

$\mathrm{Ha}_{3}$ : Ada perbedaan signifikan hasil belajar peserta didik antara model pembelajaran kontekstual dan model pembelajaran kontekstual dan inovasi guru di SD N 1 dan 3 Selang Kebumen.

Teknik pengumpulan data kuantitatif dengan menggunakan angket dan tes. Angket digunakan untuk mengetahui pendapat guru tentang pembelajaran IPS di SD N 1 dan 3 Selang. Metode tes digunakan untuk mengumpulkan data dengan alat bantu berupa tes. Teknik tes dalam penelitian ini digunakan untuk menilai dan mengukur kognitif peserta didik kelas III di SD N 1 dan 3 Selang. Soal tes dibuat sebagai pre dan posttest yang dikembangkan oleh peneliti sendiri. Tes ini diberikan kepada kelas eksperimen pertama sampai dengan keempat. Alat tes yang sama dan hasil pengolahan data digunakan untuk menguji hipotesis dalam penelitian ini. Adapun

Tabel 1. Perbandingan Variabel Penelitian

\begin{tabular}{lll}
\hline Keterangan & \multicolumn{1}{c}{ Kontekstual } & \multicolumn{1}{c}{ Inovasi } \\
\hline Perbandingan & Model & Model \\
& Pembelajaran & Pembelajaran \\
& Kontekstual & Kontekstual dan \\
& Murni & Inovasi \\
Persamaaan & Model & Model \\
& Pembelajaran & Pembelajaran \\
& Kontekstual & Kontekstual \\
Kelebihan & \multicolumn{2}{c}{ Ada inovasi pada } \\
& & $\begin{array}{l}\text { model, media, dan } \\
\text { materi. }\end{array}$ \\
& & \\
Kelemahan & Tidak ada inovasi \\
& pada model, \\
& media, dan materi. & \\
\hline
\end{tabular}

teknik analisis data dengan beberapa cara yaitu deskripsi data kemudian dilanjutkan dengan uji prasyarat analisis yang terdiri dari uji normalitas dan homogenitas. Pada tahap selanjutnya penulis melakukan pengujian hipotesis dengan cara menggunakan independent sample t test.

\section{HASIL DAN PEMBAHASAN}

Penulis untuk memperoleh data tentang model pembelajaran IPS di SD N 1 dan 3 Selang dengan menggunakan instrumen observasi. Adapun rician data instrumen observasi penulis rangkum dalam Tabel 2.

\section{Pendapat Guru Tentang Pembelajaran IPS}

Penulis untuk mengetahui tentang pembelajaran IPS di SD N 1 dan 3 Selang mengggunakan beberapa metode. Pertama penulis melakukan wawancara dengan beberapa guru yaitu kelas II, III, IV dan VI. Berdasarkan hasil wawancara diambil kesimpulan bahwa guru menyatakan sulit untuk pembelajaran IPS dengan berbagai alasan seperti materi, model, dan media pembelajaran. ${ }^{12}$ Penulis kemudian mengembangkan penemuan tersebut dengan menggunakan angket. Angket bertujuan untuk mengetahui pendapat guru dalam pembelajaran IPS. Instrumen angket juga bertujuan untuk mengecek dan memperbaiki kebenaran data dari wawancara. Adapun rincian data hasil angket sebagai berikut.

Pada Gambar 1, penulis menanyakan materi yang sulit diajarkan ke peserta didik dari lima mata pelajaran. Berdasarkan hasil angket di atas bahwa mata pelajaran yang sulit diajarkan ke peserta didik adalah Bahasa Indonesia dan IPS.

Alasan penulis memilih mata pelajaran IPS karena penulis pernah melakukan penelitian di sekolah tersebut pelajaran Bahasa Indonesia pada waktu sebelumnya. Penulis kemudian tertarik untuk meneliti lebih lanjut pada mata pelajaran IPS. ${ }^{13}$

${ }^{12}$ Olah data hasil wawancara dengan guru kelas II, III, IV dan VI di SD N 1 dan 3 Selang

${ }^{13}$ Olah data berdasarkan hasil angket tentang pendapat guru dalam pembelajaran IPS di SD N 1 dan 3 Selang 
Tabel 2. Perbandingan Pembelajaran IPS di SD N 1 dan 3 Selang

\begin{tabular}{|c|c|c|}
\hline Keterangan & SD N 1 Selang & SD N 3 Selang \\
\hline Kurikulum & KTSP & KTSP \\
\hline Modul Pembelajaran & Sama & Sama \\
\hline $\begin{array}{l}\text { Model Pembelajaran } \\
\text { a. Direct Instruction } \\
\text { b. Penugasan } \\
\text { c. Mengoreksi jawaban }\end{array}$ & Sama & Sama \\
\hline Guru & Sertifikasi & Sertifikasi \\
\hline Peserta Didik & $\begin{array}{ll}\text { a. } & \text { Mengantuk } \\
\text { b. Bermain } \\
\text { c. Bosan } \\
\text { d. Jenuh } \\
\text { e. Kompetitif } \\
\text { f. Kurang memperhatikan }\end{array}$ & $\begin{array}{ll}\text { a. } & \text { Mengantuk } \\
\text { b. Bermain } \\
\text { c. Bosan } \\
\text { d. Jenuh } \\
\text { e. Kompetitif } \\
\text { f. Kurang memperhatikan } \\
\text { g. Menggambar }\end{array}$ \\
\hline
\end{tabular}

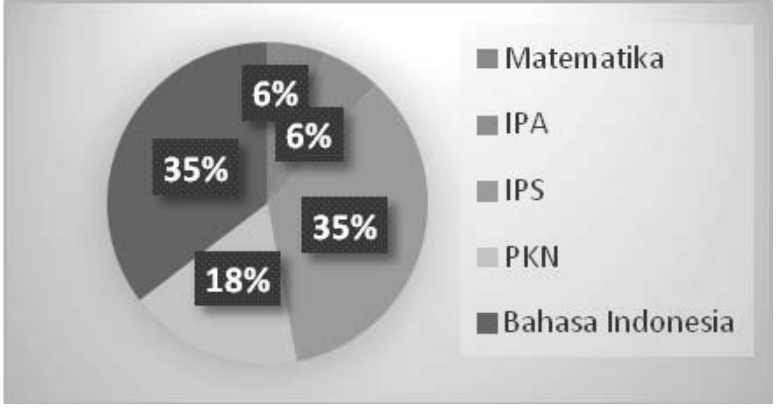

Gambar 1. Pendapat Guru Tentang Mata Pelajaran yang Sulit Diajarkan ke Peserta Didik

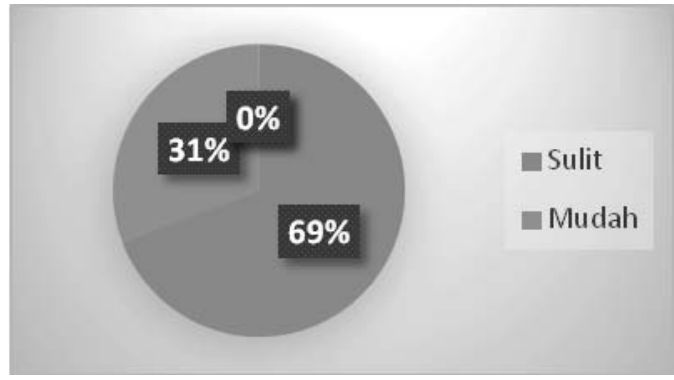

Gambar 2. Pendapat Guru Tentang IPS

Berdasarkan Gambar 2 bahwa $69 \%$ guru menyatakan sulit, dan $31 \%$ menyatakan mudah. Penulis kemudian melakukan analisis kembali tentang tingkat kesulitan guru pada pembelajaran IPS lebih dominan di kelas rendah atau di kelas tinggi. Hal ini dapat dilihat di Gambar 3.

Berdasarkan Gambar 3 menunjukan bahwa tingkat kesulitan guru pembelajaran

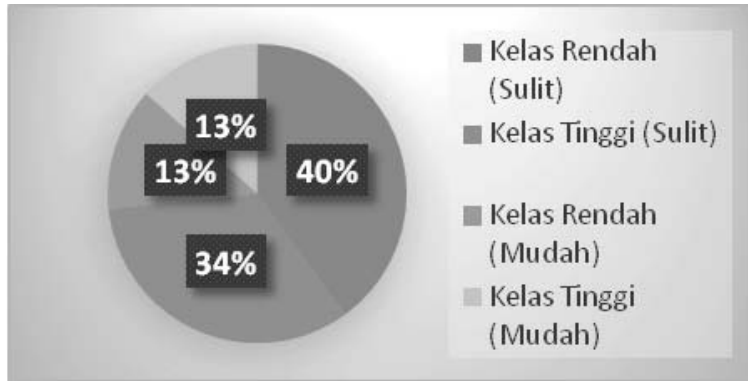

Gambar 3. Kesulitan Guru di Mata Pelajaran IPS

IPS di kelas rendah dan tinggi bermacammacam. Alasan beberapa guru menyatakan sulit pembelajaran IPS di kelas rendah. Pertama, materi peserta didik terlalu banyak. Kedua, Peserta didik menganggap mata pelajaran IPS tidak terlalu penting. Matematika lebih penting sehingga tidak tertarik kepada pelajaran IPS. Ketiga, Materi terlalu luas. Keempat, kurangnya media yang mendukung. Keempat, Guru tidak dapat menggunakan berbagai metode, guru lebih banyak menggunakan metode ceramah. Kelima peserta didik pada umur 6-9 tahun sulit untuk memahami materi. Misal pada kelas II mereka sulit membedakan materi dokumen pribadi dan keluarga. Pada materi kelas III mereka sulit membedakan jenis pekerjaan menghasilkan barang dan jasa. Keenam materi terlalu abstrak maka guru sulit menyampaikan ke peserta didik dengan contoh yang konkrit. ${ }^{29}$ 
Alasan beberapa guru yang menyatakan sulit pada kelas tinggi. Pertama, keterbatasan media yang kurang memadai. Kedua, materi yang banyak sedangkan jam mengajar relatif sedikit sehingga hanya sebagian materi yang dapat diserap oleh peserta didik. Keempat, materi IPS terlalu banyak dihafalkan. Kelima, materi IPS materi IPS yang sangat luas. ${ }^{14}$

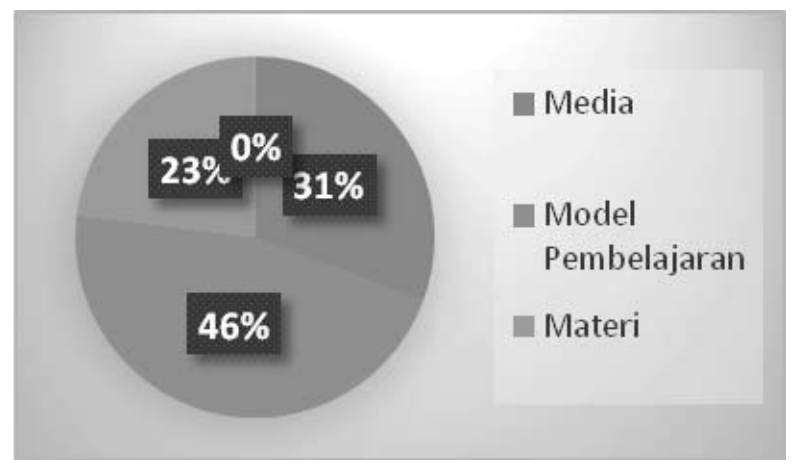

Gambar 4. Kendala Guru di Mata Pelajaran IPS

Pembelajaran IPS terkendala pada model pembelajaran adalah $46 \%$. Guru terkendala media pembelajaran IPS 31\% sedangkan materi $23 \%$. Alasan guru terkendala pada model pembelajaran pertama, guru lebih banyak menggunakan direct instruction. Kedua, guru tidak dapat menggunakan berbagai cara untuk mengajar. Ketiga guru dalam pembelajaran IPS lebih banyak monton seperti ceramah dan mengerjakan modul pembelajaran. ${ }^{15}$

Alasan guru menyatakan sulit di media sebagian besar menyatakan media yang kurang lengkap sehingga sulit untuk mencontohkan ke peserta didik misal dalam pembelajaran tentang peta. Alasan guru menyatakan sulit di bagian materi karena materi terlalu luas dan sulit untuk diajarakan ke peserta didik. ${ }^{32}$

Dari kendala yang dihadapi oleh guru maka penulis gunakan untuk melakukan inovasi di dalam pembelajaran IPS. Inovasi

${ }^{14}$ Olah data berdasarkan hasil angket tentang pendapat guru dalam pembelajaran IPS di SD N 1 dan 3 Selang

${ }^{15}$ Olah data berdasarkan hasil angket tentang pendapat guru dalam pembelajaran IPS di SD N 1 dan 3 Selang yang penulis lakukan pada eksperimen pertama dan kedua adalah pada model pembelajaran. Model pembelajaran yang penulis lakukan adalah model pembelajaran kontekstual. Inovasi media penulis lakukan pada eksperimen ketiga. Media yang penulis berikan adalah mata uang asli dan palsu, mata uang negara lain, dan uang giral.Inovasi pada materi penulis lakukakn pada eksperimen keempat. Inovasi materi yang penulis lakukan adalah dengan penambahan materi yang berfungsi untuk menanamkan nilai karakter pada peserta didik.

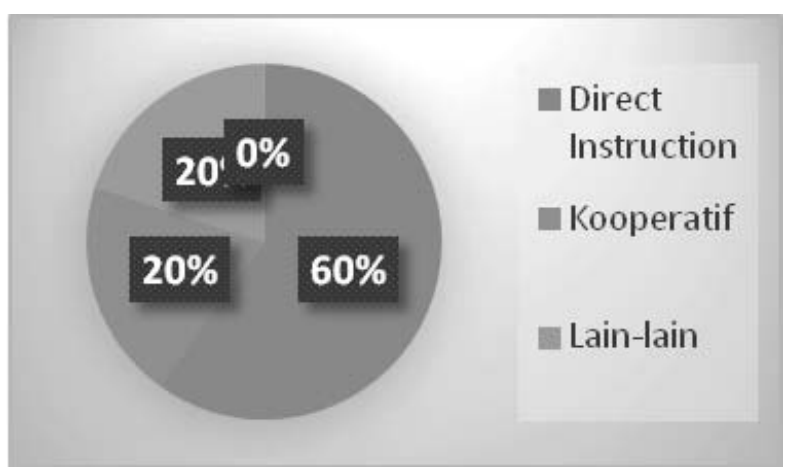

Gambar 5. Model Pembelajaran IPS

Berdasarkan Gambar 5 menunjukan bahwa $60 \%$ guru mengajarkan model pembelajaran direct instruction. Alasan guru mengajarkan dengan menggunakan model tersebut sebagian besar karena mudah diaplikasikan. Kedua, guru dapat menjelaskan masalahmasalah. Alasan guru menggunakan model kooperatif karena peserta didik mudah mempelajari pembelajaran IPS. Kedua, peserta didik lebih terpancing lebih aktif. Ketiga pembelajaran IPS sering mangajarkan metode diskusi kelompok. Keempat, dengan kooperatif peserta didik dapat berlatih musyawarah dalam mengambil keputusan dan peserta didik belajar menghargai pendapat. Guru yang menjawab lain-lain degan menggunakan role playing. Role playing bertujuan peserta didik seolah-olah menjadi tokoh tersebut sehingga materi akan mudah diingat. ${ }^{33}$ 
Hasil Belajar Peserta Didik antara Model Pembelajaran Kontekstual dan Inovasi Guru di SD $\mathbf{N} 1$ dan 3 Selang

\section{Analisis Kognitif}

Pada penelitian eksperimen ini penulis melakukan eksperimen empat kali. Berikut hasil belajar peserta didik dilihat dari skor rata-rata antara kelas eksperimen dengan kelas kontrol dengan menggunakan penghitungan empiris pada Tabel 3.

Tabel 3. Perbandingan Rata-rata Nilai Kognitif Kelas Eksperimen dan Kontrol

\begin{tabular}{lcc}
\hline Keterangan & Eksperimen & Kontrol \\
\hline Eksperimen 1 & 85 & 83,78 \\
Eksperimen 2 & 85 & 83,47 \\
Eksperimen 3 & 78,57 & 69,46 \\
Eksperimen 4 & 87,30 & 85,71 \\
\hline
\end{tabular}

Dari Tabel 3 dapat disimpulkan bahwa kelas eksperimen lebih unggul dibandingkan kelas kontrol. Penulis kemudian ingin melihat perbedaan signifikansi dengan menggunakan alat SPSS 20,0. Berikut hasil pengghitungan SPSS 20,0 pada Tabel 4.

Tabel 4. Hasil Uji Hipotesis Pada ranah Kognitif

\begin{tabular}{rll}
\hline Eksperimen & Hasil Uji Hipotesis & Keputusan \\
\hline Eksperimen 1 & $0,302>0,05$ & Ho diterima \\
Eksperimen 2 & $0,244>0,05$ & Ho diterima \\
Eksperimen 3 & $0,081>0,05$ & Ho diterima \\
Eksperimen 4 & $0,923>0,05$ & Ho diterima \\
\hline
\end{tabular}

Dari Tabel 4 menunjukan bahwa nilai signifikansi lebih dari 0,05. Apabila nilai Asymp Sig (2tailed) lebih dari 0,5 maka Ho diterima.
Dengan demikian hasil belajar peserta didik pada ranah kognitif tidak memberikan pengaruh yang signifikan terhadap hasil belajar peserta didik.

\section{Analisis Afektif}

Berdasarkan pada Tabel 5 bahwa pada eksperimen pertama penulis menemukan bahwa kelas eksperimen memberikan pengaruh yang cukup signifikan terhadap sikap peserta didik. Sikap peserta didik dari sisi keaktifan mereka lebih cepat dalam mengerjakan diskusi kelompok hal ini berbeda dari kelas kontrol yang selalu bertanya kepada guru. Hal ini disebabkan koperasi sekolah di SD N 1 Selang merupakan contoh konkrit kegiatan jual beli di lingkungan sekolah.

Peserta didik yang menggunakan kelas eksperimen mereka lebih percaya diri dalam mengerjakan diskusi kelompok. Peserta didik lebih banyak aktif dibandingkan dengan kelas kontrol. Peserta didik dalam hal kerjasama mereka saling membantu misal menuliskan secara bergantian, bagi peserta didik yang belum berpendapat diminta pendapatnya, jika ada peserta didik yang tidak bersedia bekerjasama dilaporkan ke guru. Peserta didik dari sisi tanggungjawab mereka lebih antusias khususnya ketika pengamatan di kantin dan koperasi sekolah.

Pada eksperimen kedua dapat ditarik kesimpulan bahwa peserta didik yang menggunakan kelas ekperimen memiliki perbedaan sikap yang signifikan. Peserta didik

Tabel 5. Perbandingan Persentase Sikap Peserta Didik Kelas Eksperimen danKontrol

\begin{tabular}{llll}
\hline Eksperimen & Kelas Kontrol & Kelas Eksperimen & Keputusan \\
\hline Eksperimen 1 & Aktif 61\%, & Aktif 71\% & Ha diterima \\
& kerjasama 65\%, & Kerjasama 70\%, & \\
& Tanggunngjawab 57\% & Tanggunngjawab 69\% & \\
Eksperimen 2 & Aktif 68\% kerjasama 72\% & Aktif 86\%, kerjasama 85\%, & Ha diterima \\
& Tanggunngjawab 50\% & Tanggungjawab 85\% & \\
Eksperimen 3 & Aktif 74\%, Kerjasama 86\%, & Aktif 85\%, & Ha diterima \\
& Tanggungjawab 74\%. & Kerjasama 95\%, & \\
Eksperimen 4 & Aktif 89\%, & Tanggunngjawab 90\% & \\
& Kerjasama 79\%, & Aktif 87\%, & \\
& Tanggunngjawab 65\% & Kerjasama 92\%, & \\
& & Tanggungjawab 69\% & \\
\hline
\end{tabular}


pada kelas eksperimen, mereka dengan mudah mendiskusikan barang-barang yang dijual di lingkungan rumah sesuai dengan jenisnya misal toko, warung makan, apotik, pasar modern dan tradisional. Kelas kontrol ada beberapa kelompok yang sulit mengelompokan jenis-jenis barang yang dijual misal ada suatu kelompok menempelkan sayuran yang dijual di apotik. Maka kelas eksperimen lebih aktif dan bekerjasama lebih unggul dibandingkan kelas kontrol karena kelas eksperimen telah melakukan tugas proyek di lingkungan rumah.

Sikap tanggungjawab peserta didik pada kelas eksperimen sangat berbeda. Mereka lebih semangat dalam menggunting barang-barang yang dijual di lingkungan rumah. Bahkan ada beberapa kelompok yang membagi peran misal menggunting, menempel, menulis tanpa arahan dari guru. Oleh sebab itu seorang guru perlu melakukan inovasi pada model pembelajaran dalam pembelajaran di dalam kelas sehingga peserta didik tidak jenuh dalam belajar khususnya IPS.

Pada eksperimen ketiga bahwa media sangat mempengaruhi pembelajaran di dalam kelas khususnya sikap. Berdasarkan pengamatan penulis bahwa peserta didik yang menggunakan kelas eksperimen lebih semangat dan antusis dalam mengamati ciri-ciri uang kartal. Peserta didik dalam mengamati ciri-ciri uang kartal persentase menjawab benar lebih besar dibandingkan kelas kontrol. Bahkan ada beberapa kelompok yang membandingkan uang baru seperti uang $\mathrm{Rp} 5.000,00$ dengan $\mathrm{Rp}$ $10.000,00$.

Menurut pengamatan penulis bahwa kerjasama pada kelas eksperimen mereka lebih kompak dibandingkan kelas kontrol. Peserta didik dalam bekerjasma lebih kreatif dalam menjawab lembar diskusi misal uang logam tidak mudah basah dibandingkan uang kertas. Penulis menganggap imajinasi peserta didik dalam bekerjasama lebih tinggi dibandingkan kelas kontrol.

Menurut pengamatan penulis bahwa tanggungjawab pada kelas eksperimen mereka lebih kompak dibandingkan kelas kontrol. Hal ini dapat terlihat semua kelompok bersedia untuk membagi tugas, karena pertemuan sebelumnya di kelas eksperimen hanya beberapa kelompok yang membagi peran dalam bekerjasama. Kelas kontrol penulis melihat hanya peserta didik yang selalu bertanggungjawab di dalam kelompoknya misal hanya satu anak yang menulis. Ada beberapa anak yang kadangkadang masih mengobrol dengan temannya sehingga penulis menganggap kurangnya rasa tanggungjawaab peserta didik terhadap kelompoknya.

Pada eksperimen keempat, bahwa inovasi materi sangat mempengaruhi pembelajaran di dalam kelas khususnya sikap. Berdasarkan pengamatan penulis bahwa peserta didik yang menggunakan kelas eksperimen lebih mudah menerima materi. Keaktifan peserta didik dalam bekerja kelompok tidak tergantung pada guru. Mereka lebih mengemukakan pendapat kelompok dibandingkan bertanya kepada guru. Bahkan ada beberapa kelompok yang kreatif dalam mengemukakan pendapatnya misal menabung di bank kelebihannya bisa mengatahui jumlah uang dan mendapatkan buku tabungan.

Menurut pengamatan penulis bahwa kerjasama yang dilakukan oleh kelompok kontrol lebih tergantung pada guru. Mereka sulit untuk mengemukakan pendapatnya ketika mereka mengisi lembar diskusi. Bahkan ada anggota suatu kelompok yang tidak mau bekerjasama dikarenakan materi yang cukup sulit. Dengan demikian inovasi materi penting agar melatih sikap peserta didik.

\section{Analisis Psikomotorik}

Pada Tabel 6 kelas eksperimen dilakukan oleh guru adalah pada tahap inkuiri. Inkuiri yang dilakukan di rumah dengan tugas proyek. Peserta didik yang melakukan inkuiri lebih terampil dalam mengamati barangbarang. Peserta didik dengan diberi tugas proyek maka peserta didik terlatih bersikap mandiri. Peserta didik belajar pada lingkungan sosial di sekitar mereka. Peserta didik dengan belajar dengan lingkungan sekitar belajar berinteraksi dan tidak 
Tabel 6. Perbandingan Psikomotorik Kelas Eksperimen dan Kontrol

\begin{tabular}{|c|c|c|c|}
\hline \multirow{2}{*}{ Eksperimen } & \multicolumn{3}{|c|}{ Uji Hipotesis Psikomotorik } \\
\hline & Kontrol & Eksperimen & Keputusan \\
\hline Eksperimen 1 dan 2 & $\begin{array}{l}\text { Mencermati barang-barang selalu cermat } \\
42 \% \text {. }\end{array}$ & $\begin{array}{l}\text { Mencermati barang barang selalu } \\
\text { cermat } 65 \% \text {, }\end{array}$ & Ha diterima \\
\hline & Menyimpulkan jenis barang $69 \%$. & Menyimpulkan jenis barang $80 \%$ & \\
\hline Eksperimen 3 dan 4 & $\begin{array}{l}\text { Mengelola uang sesuai kebutuhan sekolah } \\
33 \% \text {. }\end{array}$ & $\begin{array}{l}\text { Mengelola uangsesuai kebutuhan } \\
\text { sekolah } 40 \%\end{array}$ & Ha diterima \\
\hline & Sering menabung $78 \%$ & Sering menabung $91 \%$ & \\
\hline
\end{tabular}

malu. Peserta didik mendapatkan pengetahuan yang lebih dibandingkan pada kelas kontrol misal hargaharga kebutuhan rumah.

Berdasarkan pengamatan penulis bahwa jika suatu kelompok dalam mengamati barang-barang benar maka peserta didik akan menyimpulkan dengan benar. Jika jika suatu kelompok dalam mengamati barangbarang kadang benar maka peserta didik akan menyimpulkan kadang dengan benar. Dengan demikian inovasi yang dilakukan oleh guru mempengaruhi peserta didik dalam menyimpulkan hasil pengamatan.

Eksperimen pada penilaian proyek di SD N 1 Selang. Kelas kontrol adalah SD N 3 Selang. Tugas penilaian proyek adalah cara peserta didik mengelola uang dan menabung dalam waktu satu minggu. Analisis pengelolaan uang dapat dilihat pada diagram lingkaran sebagai berikut:

Beradasarkan pengamatan penulis perbedaan antara di kelas kontrol dan eksperimen disebabkan inovasi materi. Pada inovasi materi penulis di kelas eksperimen dengan menambahkan bank sebagai pengetahuan baru bagi peserta didik. Pada modul pembelajaran disebutkan tetapi hanya sedikit maka penulis memperluas materi guna penanaman karakter yaitu menabung. Analisis lebih lanjut dapat dilihat diagram lingkaran berikutnya.

Hasil pengamatan penulis bahwa peserta didik yang pandai mengelola uang artinya mengelola uang sesuai dengan kebutuhan sekolah mereka akan selalu menabung. Peserta didik yang belum pandai mengelola uang terkadang mereka tidak selalu menabung dalam setiap minggungnya. Maka dapat ditarik kesimpulan seorang guru harus melakukan inovasi agar karakter peserta didik dapat dimunculkan.

\section{KESIMPULAN}

Secara kuantitatif model pembelajaran kontekstual berpengaruh secara signifikan terhadap hasil belajar peserta didik pada ranah kognitif, terlihat dari hasil uji man whitney $u$ menunjukan bahwa lebih dari 0,05. Secara kualitatif model pembelajaran kontekstual melalui inovasi guru berpengaruh terhadap hasil belajar peserta didik pada ranah afektif dan psikomotorik, terlihat dari perilaku peserta didik seperti sikap kerjasama, tanggungjawab dan aktif, pada psikomotorik perilaku peserta didik lebih terampil menyimpulkan, mengamati, mengelola uang, dan menabung.

Secara kuantitatif pengaruh model pembelajaran kontekstual terhadap hasil belajar peserta didik berpengaruh secara signifikan pada ranah kognitif ditunjukan oleh nilai posttest dengan hasil uji mann whiteney u lebih dari 0,05 . Secara kualitatif pengaruh model pembelajaran kontekstual melalui inovasi guru terhadap hasil belajar peserta didik pada ranah sikap dan psikomotorik, terlihat dari perilaku peserta didik seperti tanggungjawab, aktif, kerjasama, mengamati, menyimupulkan, mengelola uang, dan menabung.

\section{DAFTAR PUSTAKA}

Al Rais, Heppy, Kamus Ilmiah Populer. (Yogyakarta: Pustaka Pelajar, 2012)

Clemente Charles HUDSON dan Vesta R. WHISLER. "Contextual Teaching and Learning for Practitioners," (Jurnal: 
Systemics, cybernetics and informatics. Volum 6. No 4. Tahun 2008)

Johnson, Elaine B, Contextual Teaching And Learning: Menjadikan Kegiatan Belajar Mengajar Mengasyikan Dan Bermakna, Terj. Ibnu Setiawan. (Bandung: Mizan Learning Centre. 2007.)

Olah data hasil wawancara dengan guru kelas II, III, IV dan VI di SD N 1 dan 3 Selang

Olah data berdasarkan hasil angket tentang pendapat guru dalam pembelajaran IPS di SD N 1 dan 3 Selang

Sanjaya, Wina, Strategi Pembelajaran Berorientasi Standar Proses Pendidikan, (Jakarta: Prenada Media, 2007)

Sardjiyo, dkk. Pendidikan IPS, (Tangerang Selatan: Universitas Terbuka, 2014.)
Trianto. Mendesain Model Pembelajaran Inovatif, Progresif: Konsep, Landassan, dan Implementasinya pada Kurikulum Tingkat Satuan Pendidikan. (Jakarta: Kencana Media Grup, 2012)

Wahyudin, Din dkk, Pengantar Pendidikan, (Jakarta: Universitas Terbuka, 2010)

W. Creswell, John. Research Design: Pendekatan Kualitatif, Kuantitatif, dan Mixed, (Yogyakarta: Pustaka Pelajar, 2009)

Sugiyono, Metode Penelitian Kombinasi. Mixed Methods, (Bandung: Alfabeta, 2013)

Winataputra, Udin S dkk, Pembaharuan Pendidikan di SD, (Jakarta: Universitas Terbuka, 2011)

Yani, Ahmad., Modul Pembelajatan IPS. (Jakarta: Direktorat Jenderal Pendidikan Islam, 2012) 